\title{
Interfacial Behavior and Shear Strength of Al-25Si-4Cu-1Mg Joints by Transient Liquid Phase Bonding with $\mathrm{Cu}$ as Interlayer
}

\author{
Kai Qi, Guo Xu and Fengjiang Wang *(D) \\ School of Materials Science and Engineering, Jiangsu University of Science and Technology, \\ Zhenjiang 212003, China; qikai@just.edu.cn (K.Q.); wangyan451@gmail.com (G.X.) \\ * Correspondence: fjwang@just.edu.cn; Tel.: +86-511-8440-1184
}

check for updates

Citation: Qi, K.; Xu, G.; Wang, F. Interfacial Behavior and Shear Strength of Al-25Si-4Cu-1Mg Joints by Transient Liquid Phase Bonding with $\mathrm{Cu}$ as Interlayer. Metals 2021, 11, 1637. https://doi.org/10.3390/ met11101637

Academic Editors: Babak

Shalchi Amirkhiz and

Frank Czerwinski

Received: 7 August 2021

Accepted: 12 October 2021

Published: 14 October 2021

Publisher's Note: MDPI stays neutral with regard to jurisdictional claims in published maps and institutional affiliations.

Copyright: (c) 2021 by the authors. Licensee MDPI, Basel, Switzerland. This article is an open access article distributed under the terms and conditions of the Creative Commons Attribution (CC BY) license (https:/ / creativecommons.org/licenses/by/ $4.0 /)$.

\begin{abstract}
Spray-formed hypereutectic Al-Si-Cu-Mg alloy is the candidate for automotive and aerospace industries due to its superior wear resistance, lower thermal expansion coefficient and density, and higher thermal conductivity. This paper aims to investigate the bonding properties of hypereutectic $\mathrm{Al}-25 \mathrm{Si}-4 \mathrm{Cu}-1 \mathrm{Mg}$ alloys using the transient liquid phase (TLP) method with $\mathrm{Cu}$ as an interlayer. To obtain the suitable bonding parameters, the interfacial microstructure and shear strength of Al-25Si-4Cu-1Mg joints were investigated with the effect of different bonding temperatures and holding times. The results showed that TLP bonding between Al-Si-Mg-Cu alloy was mainly realized by large amounts of $\mathrm{Al}_{2} \mathrm{Cu}$ intermetallic compounds (IMCs), primary $\mathrm{Si}$ and $\alpha-\mathrm{Al}$ phases. With the brazing temperature increasing, the width of the brazing seam gradually increased, and the voids began to be produced. With the holding time increasing, $\theta-\mathrm{Al}_{2} \mathrm{Cu}$ phases approached into the base metal and Si particles in the brazing seam were obviously coarsened. With the formation of $\theta-\mathrm{Al}_{2} \mathrm{Cu}$ phases into the base metal, more $\mathrm{Si}$ particles were segregated at the interface between brazing seam and base metal, and the shear test confirmed that it was the weakest bonding location. Finally, the effect of bonding parameters on the joint strength indicated that the joint brazed at $540{ }^{\circ} \mathrm{C}$ for $7.5 \mathrm{~min}$ presented the best shear performance with the shear strength reaching $75 \mathrm{MPa}$ because the size of Si particles in the brazing seam was closest to the size of Si particles in base metal under this parameter.
\end{abstract}

Keywords: Al-Si-Cu-Mg alloy; spray forming; transient liquid phase bonding; shear strength

\section{Introduction}

The hypereutectic Al-Si alloy is a unique aluminum alloy in which dispersed Si particles are embedded in the surrounding $\alpha$-Al matrix. Si particles are typically hard and brittle materials, and their thermal expansion coefficient is lower than $\mathrm{Al}$. The $\alpha$-Al matrix is soft and highly malleable and has a high thermal expansion coefficient [1]. By changing the ratio of $\mathrm{Al}$ and $\mathrm{Si}$, hypereutectic $\mathrm{Al}-\mathrm{Si}$ alloy can obtain its bias performance, such as lightweight, high strength, high thermal conductivity, controllable thermal expansion coefficient, and good machinability. It also serves as an optimal electronic packaging material [2,3] because it meets the requirements of electronic packaging technology in the direction of miniaturization, lightweight, and high-density assembly. Therefore, these Al-Si alloys have wide application prospects in the fields of electronic packaging and the automobile industry [4-7]. To apply the hypereutectic Al-Si alloy, the research on alloy connection performance is inevitable, for example, two hypereutectic Al-Si alloys need to be connected to form a sealed integrated circuit for signal transmission. Therefore, the research on the joint performance of hypereutectic Al-Si alloy is very important for its industrial application.

Spray-formed Al-Si alloy has better performance than traditional casting alloy [8-10]. Spray-forming material is characterized by rapid solidification in which the liquid metal is atomized in an inert gas atmosphere and sprayed onto the substrate or collector in the form 
of fine droplets. Therefore, spray forming technology produces high-quality hypereutectic Al-Si alloys by controlling parameters such as the ratio of liquid metal to inert gas, the flow rate of liquid metal, and the pressure of inert gas. The spray-formed hypereutectic $\mathrm{Al}-\mathrm{Si}$ alloy benefits from rapid cooling to obtain the uniform distribution for primary $\mathrm{Si}$ in the microstructure [11].

The spray-formed Al-Si alloys are also important to realize the bonding between them. However, the joining of Al-Si alloys is rarely reported, which limits their application. Fusion welding is the most common welding technique. Some researchers have tried to use a fusion welding method to connect the eutectic Al-Si alloy, but excessive welding temperature and a large amount of heat input can transform the dispersed $\mathrm{Si}$ particles into coarse primary Si phases [12]. Similarly, Lotfi B et al. [13] with tungsten inert gas shielded welding and Zhang [14] with $\mathrm{CO}_{2}$ gas shielded laser welding cannot solve the problem of coarse Si phases. On the other hand, the joining of hypereutectic Al-Si alloy is investigated with low-temperature technology. Liu [15] et al. welded Al-Si alloy by friction stir welding, and a fine Al-Si eutectic structure was formed in the joint. The transient liquid phase (TLP) brazing method has been successfully used for joining Albased composite materials [16,17], and its application on Al-Si alloys was also investigated. Wang et al. [18-21] completed the joining of Al-Si alloy by transient liquid phase brazing under ultrasonic induction with Zn-based solder and Sn-51In solder. Xu [22] et al. successfully completed the welding between 6061 aluminum alloy and Al-27Si alloy with transient liquid phase brazing. Sun et al. [23] studied the transient liquid phase brazing between high-silicon aluminum alloys with different $\mathrm{Si}$ contents, and successfully realized the metallurgical combination of Al-27Si alloy and Al-50Si alloy.

Research on spray-formed high-silicon aluminum alloy has been ongoing for many years, and many researchers have tried to control the content of Si element in the material more carefully by adding some trace elements into the high-silicon aluminum alloy to improve the performance of the alloy. These improved alloys can better adapt to their application fields, but there is inadequate research on the joining of these improved highsilicon aluminum alloys [3,24-26]. This paper aims to study the TLP brazing of Al-25Si$4 \mathrm{Cu}-1 \mathrm{Mg}$ spray-formed alloy. Al-25Si-4Cu-1Mg alloy is a hypereutectic $\mathrm{Al}-\mathrm{Si}$ alloy with $\mathrm{Cu}$ and $\mathrm{Mg}$ addition in which the formation of $\mathrm{Al}_{2} \mathrm{Cu}$ precipitation and $\mathrm{Mg}_{2} \mathrm{Si}$ or $\mathrm{AlCuMgSi}$ phases was helpful to improve the mechanical properties [25,27]. Pure $\mathrm{Cu}$ was selected as the intermediate layer because $\mathrm{Cu}$ is an element capable of solid solution strengthening and precipitation hardening in $\mathrm{Al}$, and $\mathrm{Cu}$ can improve the high temperature and normal temperature performance of $\mathrm{Al}-\mathrm{Si}$ alloy. Moreover, the ternary eutectic temperature of $\mathrm{Al}-\mathrm{Cu}-\mathrm{Si}$ is as low as $522{ }^{\circ} \mathrm{C}$ [28], which was helpful to produce TLP phases during diffusion brazing. The effect of brazing temperature and holding time on the microstructure and mechanical properties of joints was studied.

\section{Materials and Methods}

The base metal in this experiment is a spray-formed hypereutectic Al-Si-Mg-Cu alloy with the chemical compositions (wt. $\%$ ) of $1 \% \mathrm{Mg}, 4 \% \mathrm{Cu}, 25 \% \mathrm{Si}$, and balance $\mathrm{Al}$. After spray forming, the alloy was then finished with hot extrusion at $440{ }^{\circ} \mathrm{C}$ with a rate of $0.3-0.5 \mathrm{~mm} / \mathrm{s}$ to decrease the voids that occurred in spray forming. The rectangular specimens with a size of $20 \mathrm{~mm} \times 10 \mathrm{~mm} \times 2 \mathrm{~mm}$ were cut from the alloy with electronic discharge machining (EDM). Before bonding, the surface to be bonding was metallurgically polished to a surface finish of $0.05 \mu \mathrm{m}$ using colloid silica solution.

The intermediate layer material is a pure $\mathrm{Cu}$ foil with a purity of $99.7 \%$ and thickness of $30 \mu \mathrm{m}$. It was cut into a rectangle with a size of $10 \mathrm{~mm} \times 1 \mathrm{~mm}$. The surface oil and oxide film were cleaned in an ultrasonic cleaner with $5 \%$ nitric acid and alcohol, respectively.

The experiment was completed with the vacuum brazing furnace from Triumph Vacuum Company. The equipment consists of a furnace body, vacuum system, cooling system, and gas protection system. 
The samples were brazed by lap joints with a self-made fixture, as shown in Figure 1a, and the lap width between two pieces of Al-Si-Mg-Cu pieces was $1 \mathrm{~mm}$. During diffusion bonding, the vacuum was about $1 \times 10^{-2} \mathrm{~Pa}$, and the holding pressure on the sample was about $10 \mathrm{~N}$. This paper aims to study the influence of brazing temperature and holding time on transient liquid phase brazing. To study the effect of brazing temperature, because the ternary eutectic temperature of $\mathrm{Al}-\mathrm{Si}-\mathrm{Cu}$ is $522^{\circ} \mathrm{C}$, the brazing temperature was set as $535,540,545$, and $550{ }^{\circ} \mathrm{C}$, respectively, while the holding time at peak temperature was kept constant for $10 \mathrm{~min}$. To study the effect of holding time, the brazing temperature was maintained at $540{ }^{\circ} \mathrm{C}$, while the holding time was set at 5, 7.5, 10, 12.5, and $15 \mathrm{~min}$, respectively. The heating rate during brazing was $10^{\circ} \mathrm{C} / \mathrm{min}$. After diffusion bonding, furnace cooling was adopted. The related bonding parameters are plotted in Figure $1 \mathrm{~b}$.

(a)

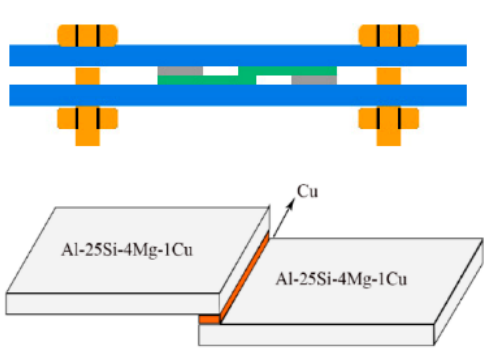

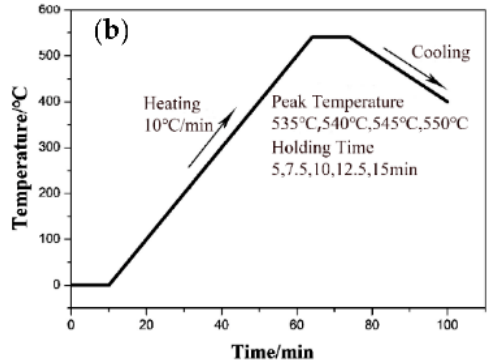

Figure 1. Schematic diagrams on (a) the lap joint of the sample and (b) brazing parameters and temperature curve.

The brazing joints were cross-sectioned, polished, and then observed with a scanning electron microscope (SEM) equipped with an energy-dispersive X-ray spectrum (EDS). To assess the mechanical properties of joints, a shear performance analysis was carried out at room temperature with a universal tensile machine under the shear rate of $0.2 \mathrm{~mm} / \mathrm{s}$. Four samples for each parameter were tested to obtain the average strength of joints. The fracture morphology was also observed with SEM. In order to explore the evolution of Si particles from the base material to the brazing seam, ImageJ software from the National Institutes of Health was used to measure the particle size and distribution of Si particles.

\section{Results}

\subsection{Characterization of the as-Received Al-25Si-4Cu-1Mg Alloy}

Figure 2 shows the microstructure and element distribution of Al-25Si-4Cu- $1 \mathrm{Mg}$ alloy prepared by the spray forming method. From Figure $2 \mathrm{a}$, it can be clearly seen that $\mathrm{Si}$ phases exist in granular form and are almost uniformly distributed in the surrounding $\alpha$-Al matrix. The size of these Si particles is about $10 \mu \mathrm{m}$, which is much better than the coarsened plate-like primary crystal Si in the traditional casting hypereutectic Al-Si alloy. Moreover, some white particles are observed in the structure. To investigate the existence of $\mathrm{Cu}$ and $\mathrm{Mg}$, elemental distribution was scanned and the results are shown in Figure 2b-e. In Figure 2b,c, Al and Si elements are separately distributed and almost incompatible. Moreover, $\mathrm{Cu}$ and $\mathrm{Mg}$ phases are easily observed in the microstructure. Part of the $\mathrm{Cu}$ element is dispersed in the base material to play a role in dispersion strengthening, and the other part is distributed in the base material in the form of $\mathrm{Al}_{2} \mathrm{Cu}$. EDS analysis confirmed that the composition of white phases was close to $\mathrm{Al}_{2} \mathrm{Cu}$. Mg element exists in the base material in the form of a compound-it would exist as $\mathrm{Mg}_{2} \mathrm{Si}$ or $\mathrm{AlCuMgSi}$ phases. In fact, Feng et al. [25] obtained the phases in spray-formed Al-25Si-4Cu-1 Mg alloy with $X$-ray diffraction (XRD) analysis and found that $\mathrm{Cu}$ and $\mathrm{Mg}$ were existed as $\mathrm{Al}_{2} \mathrm{Cu}$ and $\mathrm{AlCuMgSi}$ phase, respectively. 


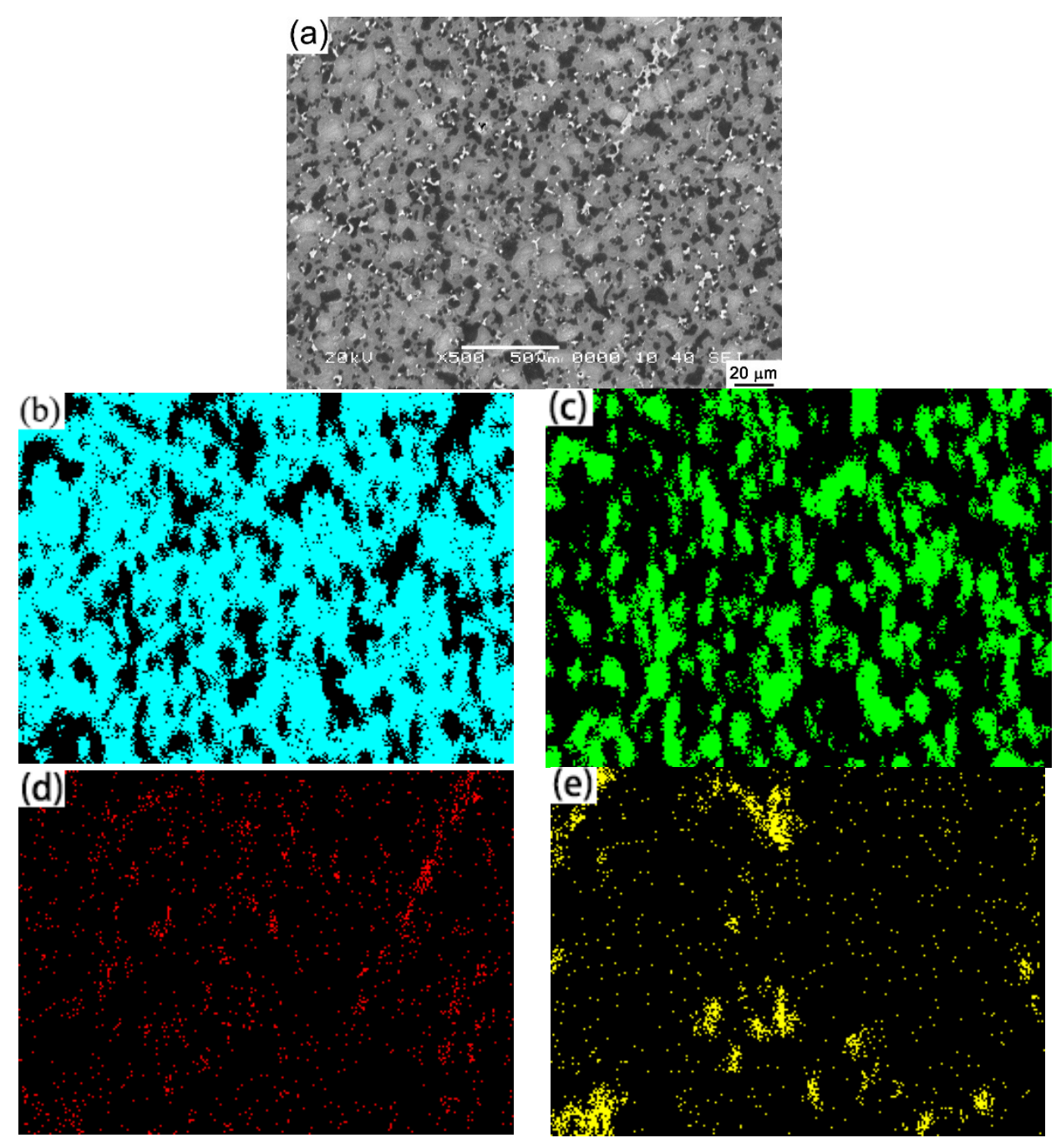

Figure 2. (a) Microstructure of the as-received $\mathrm{Al}-25 \mathrm{Si}-4 \mathrm{Cu}-1 \mathrm{Mg}$ alloy and elemental distribution of (b) $\mathrm{Al},(\mathbf{c}) \mathrm{Si}$, (d) $\mathrm{Cu}$, and (e) $\mathrm{Mg}$.

\subsection{Influence of Bonding Temperature on Microstructure of Joints}

Figure 3 shows the microstructural evolution in the brazing seam at different bonding temperatures under a constant holding time of $10 \mathrm{~min}$. The left column in Figure 3 represents the macroscopic appearance, while the right column represents the magnified observation on the brazing seam. With the temperature increasing, the width of the brazing seam increased. When the brazing temperature was $535{ }^{\circ} \mathrm{C}$, the width of the brazing seam is about $300 \mu \mathrm{m}$, as shown in Figure 3a. Because the thickness of $\mathrm{Cu}$ foil was only $30 \mu \mathrm{m}$ before brazing, the interaction between $\mathrm{Al}-25 \mathrm{Si}-4 \mathrm{Cu}-1 \mathrm{Mg}$ with $\mathrm{Cu}$ interlayer fully occurred through the transient liquid phase during the brazing process. In Figure $3 a$, we can observe lots of white phases at the center of brazing joints, which were $\mathrm{Al}_{2} \mathrm{Cu} \mathrm{IMCs}$. On the other hand, there are many voids in the joint. When the temperature increased to $540{ }^{\circ} \mathrm{C}$, as shown in Figure $3 \mathrm{~b}$, the brazing seam was perfectly formed without any voids. The width of the brazing seam is about $450 \mu \mathrm{m}$. At the center of the brazing seam, white Al-Cu IMCs and coarsened gray Si particles are uniformly distributed in the Al matrix. With the temperature continuously increasing, the brazing seam continues to expand to about $700 \mu \mathrm{m}$. However, large numbers of voids were observed in the brazing seam, as shown in Figure 3c,d. It can be seen that most of the voids were produced along the grain boundary of $\mathrm{Al}$ phases. Compared with Figure 3a,b, the increasing brazing temperature obviously promoted the growth on the width of the brazing seam. Because the eutectic temperature between $\mathrm{Al}$ and $\mathrm{Cu}$ was $548^{\circ} \mathrm{C}$, the $\mathrm{Cu}$ intermediate layer and Al-based alloy 
would undergo the eutectic reaction even without the enrollment of Si phases, resulting in the obvious diffusion of $\mathrm{Cu}$ into the $\mathrm{Al}$ matrix and accordingly a large increase in the width of the brazing seam compared to low-temperature brazing. There are some defects such as voids in the brazing seam because when the Al-Cu eutectic temperature was reached, large amounts of eutectic liquid flowed along the grain boundary of $\alpha-\mathrm{Al}$, and part of the eutectic liquid was also in contact with the primary Si. When the brazing process began cooling, the eutectic liquid solidified into a hard and brittle $\mathrm{Al}-\mathrm{Cu}$ intermetallic compound. Due to the difference in thermal expansion coefficients between $\mathrm{Al}$ and $\mathrm{Si}$, residual stress was generated during solidification, resulting in the formation of voids. From the above experiments, the optimal brazing temperature should be in between the Al-Si-Cu ternary eutectic temperature $\left(524^{\circ} \mathrm{C}\right)$ and the $\mathrm{Al}-\mathrm{Cu}$ eutectic temperature $\left(548{ }^{\circ} \mathrm{C}\right)$.

Therefore, when the brazing temperature was $540^{\circ} \mathrm{C}$, the perfect brazing seam was produced without any defects or voids. The sample with a brazing temperature of $540{ }^{\circ} \mathrm{C}$ was furtherly analyzed. During diffusion bonding between $\mathrm{Al}-\mathrm{Si}-\mathrm{Cu}-\mathrm{Mg}$ with $\mathrm{Cu}$ interlayer, $\mathrm{Al}$ atoms and $\mathrm{Cu}$ atoms were inter diffused into $\mathrm{Cu}$ interlayer and $\mathrm{Al}-\mathrm{Si}$ alloy, respectively. The Al-Si-Cu ternary eutectic temperature is $522{ }^{\circ} \mathrm{C}$ from the ternary phase diagram of Al-Si-Cu [19]. Therefore, after a short time, Al-Si-Cu eutectic composition was locally reached at the interface between the Al-Si base and $\mathrm{Cu}$ interlayer. Transient phases were produced with the ternary eutectic reaction:

$$
\theta \cdot \mathrm{Al}_{2} \mathrm{Cu}+\mathrm{Al}+\mathrm{Si} \rightarrow \mathrm{L}
$$

where $\mathrm{L}$ represents the liquid phase. With more liquid phases produced, most of the residue Si would be precipitated during the brazing process.
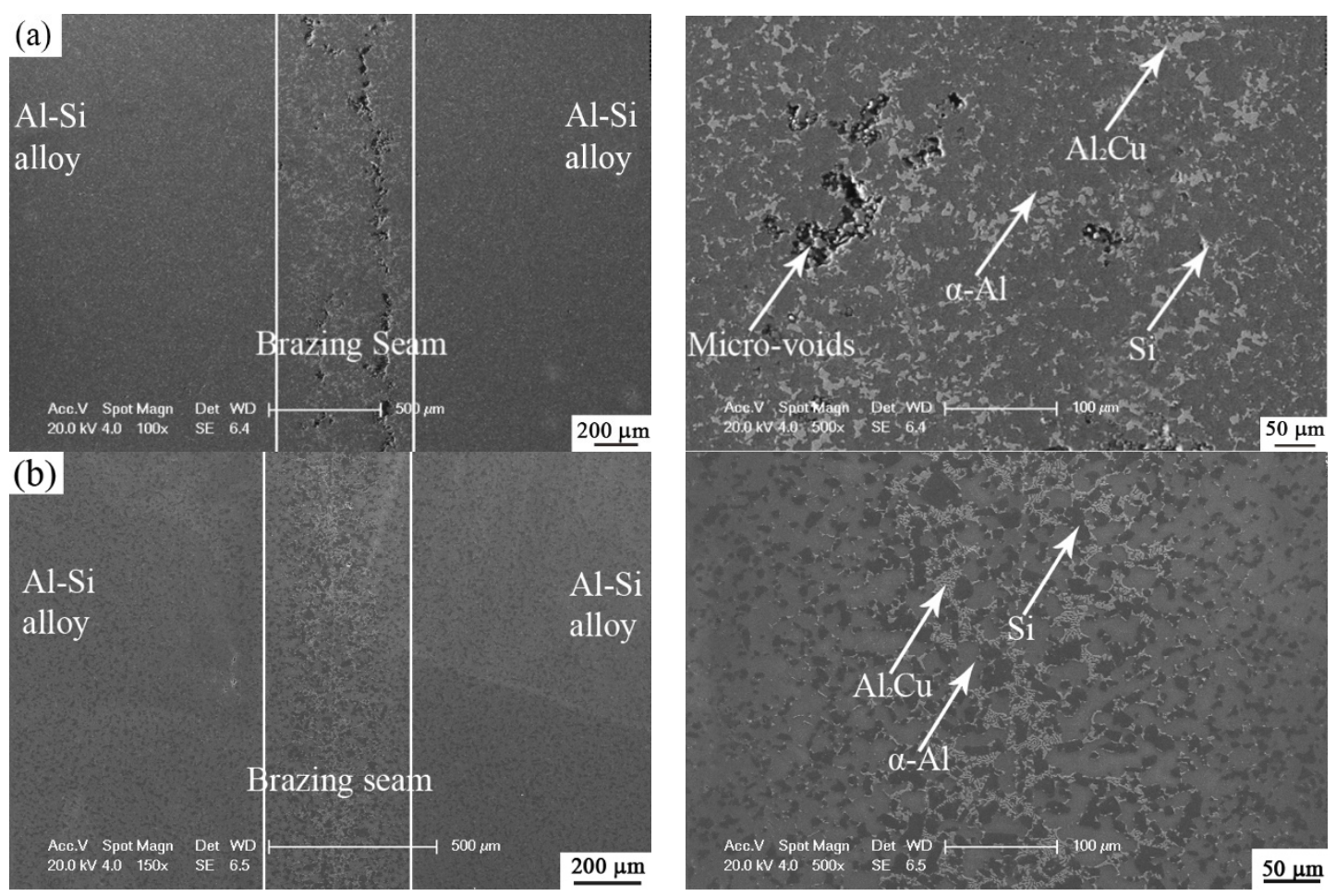

Figure 3. Cont. 

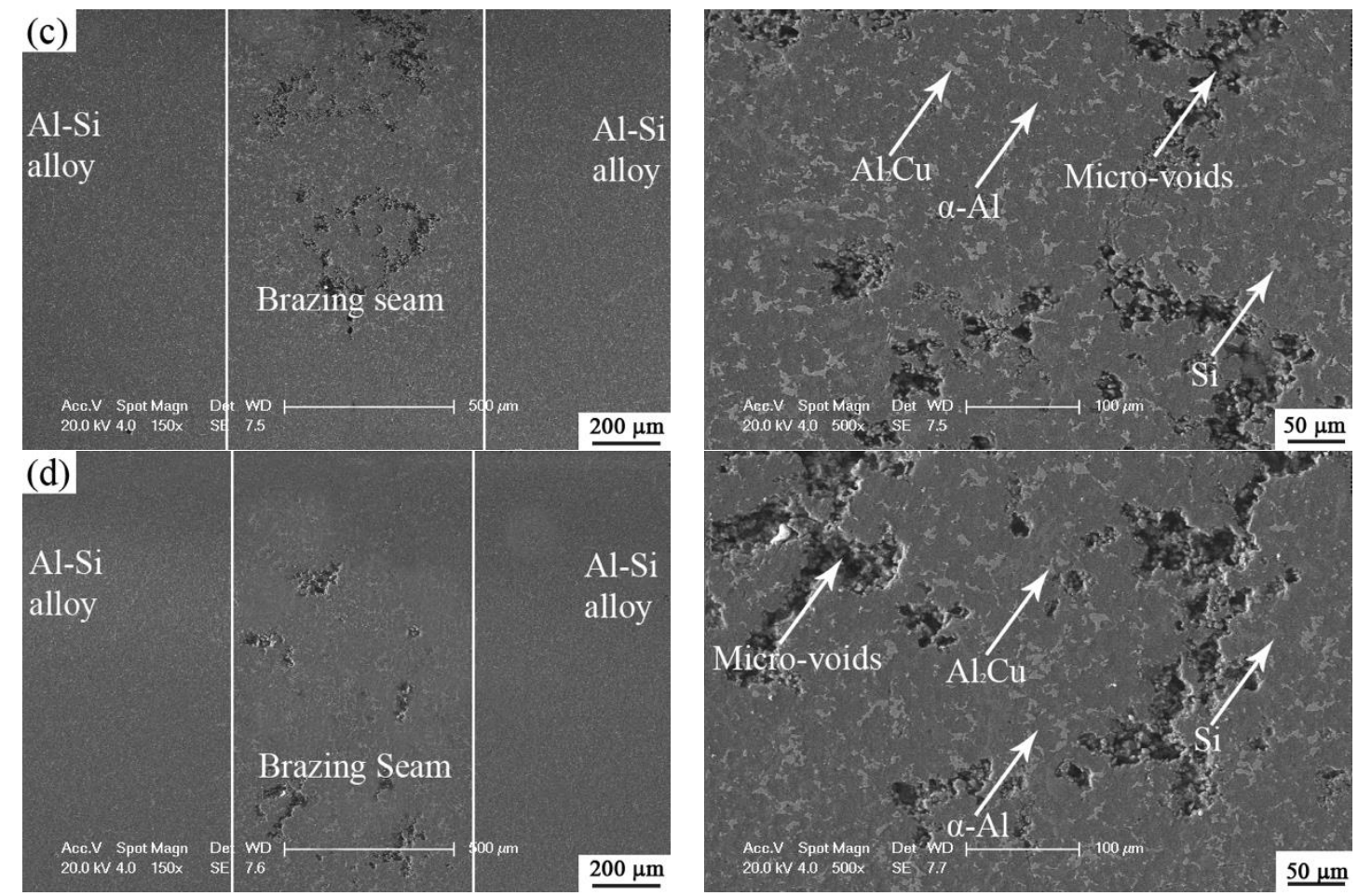

Figure 3. Microstructural evolution of brazing seam at different brazing temperatures with the constant holding time of 10 min: (a) $535^{\circ} \mathrm{C}$, (b) $540{ }^{\circ} \mathrm{C}$, (c) $545^{\circ} \mathrm{C}$, and (d) $550{ }^{\circ} \mathrm{C}$.

Figure 4 shows the interfacial microstructure in brazing joints under the brazing temperature of $540{ }^{\circ} \mathrm{C}$ for a holding time of $10 \mathrm{~min}$. Table 1 shows the results of the EDS spectrum analysis in Figure 4. Spot 1 is a dark gray Al-based solid solution $(\alpha-\mathrm{Al})$. $\mathrm{Al}$ atoms in the base metal diffused into the center of the brazing seam under high temperature and pressure, which resulted in the formation of dark gray solid solution with $\mathrm{Cu}$ as a solute solution. The bright phase shown in spot 2 is an Al-Cu intermetallic compound. According to the results of the EDS analysis, the composition of the bright phase in the brazing seam is close to $\mathrm{Al}_{2} \mathrm{Cu}$ intermetallic compound. Its appearance will usually reduce the plasticity and properties of joints, especially with a continuous layer of $\mathrm{Al}_{2} \mathrm{Cu}$. Under this parameter, coarsened Si particles were produced with the size reaching $20 \mu \mathrm{m}$, as marked with spot 3 .

The experiments in this chapter illustrated the effect of brazing temperature on the micro-morphology of joints. According to the experimental results, the optimal temperature is $540{ }^{\circ} \mathrm{C}$.

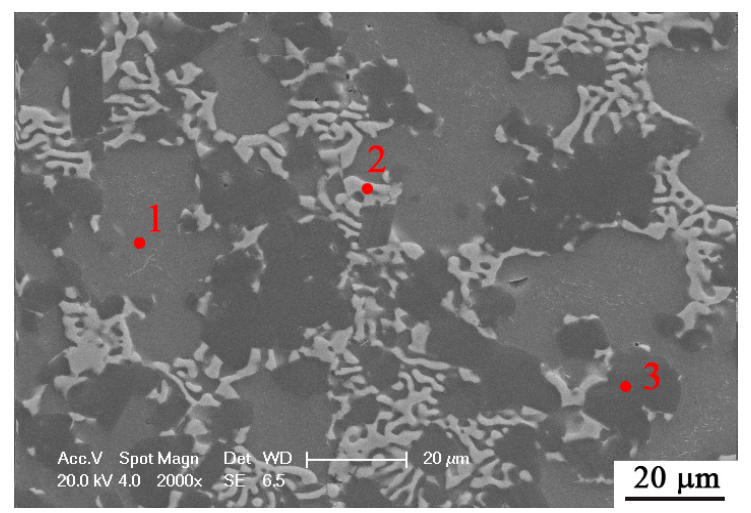

Figure 4. Microstructure and element distribution of the joint brazed at $540{ }^{\circ} \mathrm{C}$ for $10 \mathrm{~min}$. 
Table 1. Elemental composition of the marked areas in Figure 3.

\begin{tabular}{ccccc}
\hline Region & Element & wt. $\%$ & at. $\%$ & Phase \\
\hline \multirow{2}{*}{ EDS Spot 1} & $\mathrm{Al}$ & 95.9 & 98.2 & $\alpha-\mathrm{Al}$ \\
& $\mathrm{Cu}$ & 4.1 & 1.8 & 74.1 \\
\multirow{2}{*}{ EDS Spot 2 } & $\mathrm{Al}$ & 54.9 & 25.9 & $\theta-\mathrm{Al}_{2} \mathrm{Cu}$ \\
& $\mathrm{Cu}$ & 45.1 & 100.0 & $\mathrm{Si}$ \\
\hline \multirow{2}{*}{ EDS Spot 3 } & $\mathrm{Si}$ & 100.0 & & \\
\hline
\end{tabular}

\subsection{Influence of Holding Time on Microstructure of the Joints}

The purpose of this section is to investigate the effect of holding time on the microstructural evolution in the joints. The brazing temperature was set at $540{ }^{\circ} \mathrm{C}$. When the holding time was $5 \mathrm{~min}$, lots of defects were produced in the center of the brazing seam. The reason for the defect is that the eutectic liquid phase cannot completely fill in the brazing seam because of the shorter holding time. Therefore, Figure 5 mainly shows the results with a holding time from 7.5 to $15 \mathrm{~min}$. The right column represents the magnified structure on the red areas in the left column. It can be found that there is no void in the brazing seam and the joints are perfectly connected. When the holding time was $7.5 \mathrm{~min}$, as shown in Figure 5a, a brazing seam with a thickness of about $400 \mu \mathrm{m}$ was produced at the interface. There was no observation on the residual $\mathrm{Cu}$ interlayer in the center of the brazing seam, and therefore the $\mathrm{Cu}$ interlayer was fully reacted with the $\mathrm{Al}$ base metal to produce $\mathrm{Al}-\mathrm{Si}-\mathrm{Cu}$ eutectic and $\mathrm{Al}_{2} \mathrm{Cu} \mathrm{IMCs}$, which were mostly aggregated in the narrow brazing seam. White $\mathrm{Al}_{2} \mathrm{Cu}$ phases were obviously observed in the brazing seam in Figure 5a. In the Al-Si matrix, fine Si particles were uniformly distributed in $\mathrm{Al}$ phases, which was a typical spray-formed Al-Si microstructure. After the holding time was prolonged to $10 \mathrm{~min}$, as shown in Figure $5 \mathrm{~b}$, there was no obvious change to the width of the brazing seam, but the distribution of $\mathrm{Al}_{2} \mathrm{Cu}$ was transformed into a network structure around Al-rich phases. Moreover, large amounts of Al-Cu compounds accumulated in the brazing seam, while a small amount of $\mathrm{Al}-\mathrm{Cu}$ compound migrated along the grain boundary to the base metal. In the base metal, Si particles were slightly coarsened. At the interface between the brazing seam and base metal, it was interesting to find that more Si particles were segregated. With $\mathrm{Cu}$ diffusing into the Al-Si base metal, $\mathrm{Cu}$ and $\mathrm{Al}$ was reacted to produce $\mathrm{Al}_{2} \mathrm{Cu}$, and accordingly, $\mathrm{Si}$ atoms were segregated to produce clustered Si particles. With the holding time increased to $12.5 \mathrm{~min}$, as shown in Figure 5c, the thickness of the brazing seam increased to $550 \mu \mathrm{m}$. The Al-Cu compound at the center of the brazing seam was furtherly reduced. Similarly, more finely clustered Si particles were produced between the base metal and brazing seam. After the holding time was extended to $15 \mathrm{~min}, \mathrm{Cu}$ was furtherly diffused into the Al-Si base metal, by which the thickness of the brazing seam reached $850 \mu \mathrm{m}$, as seen in Figure $5 \mathrm{~d}$.

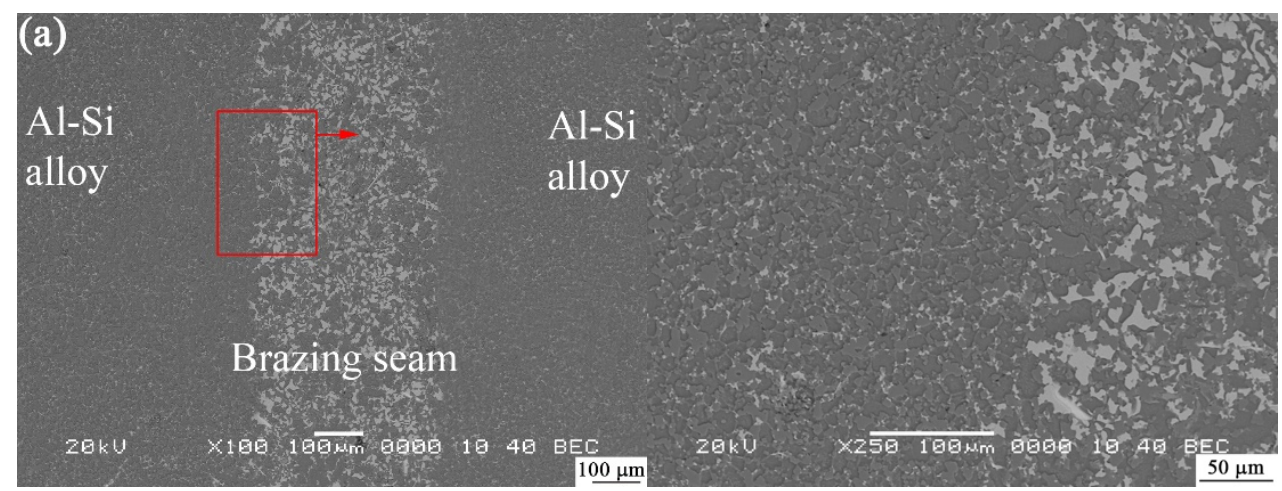

Figure 5. Cont. 

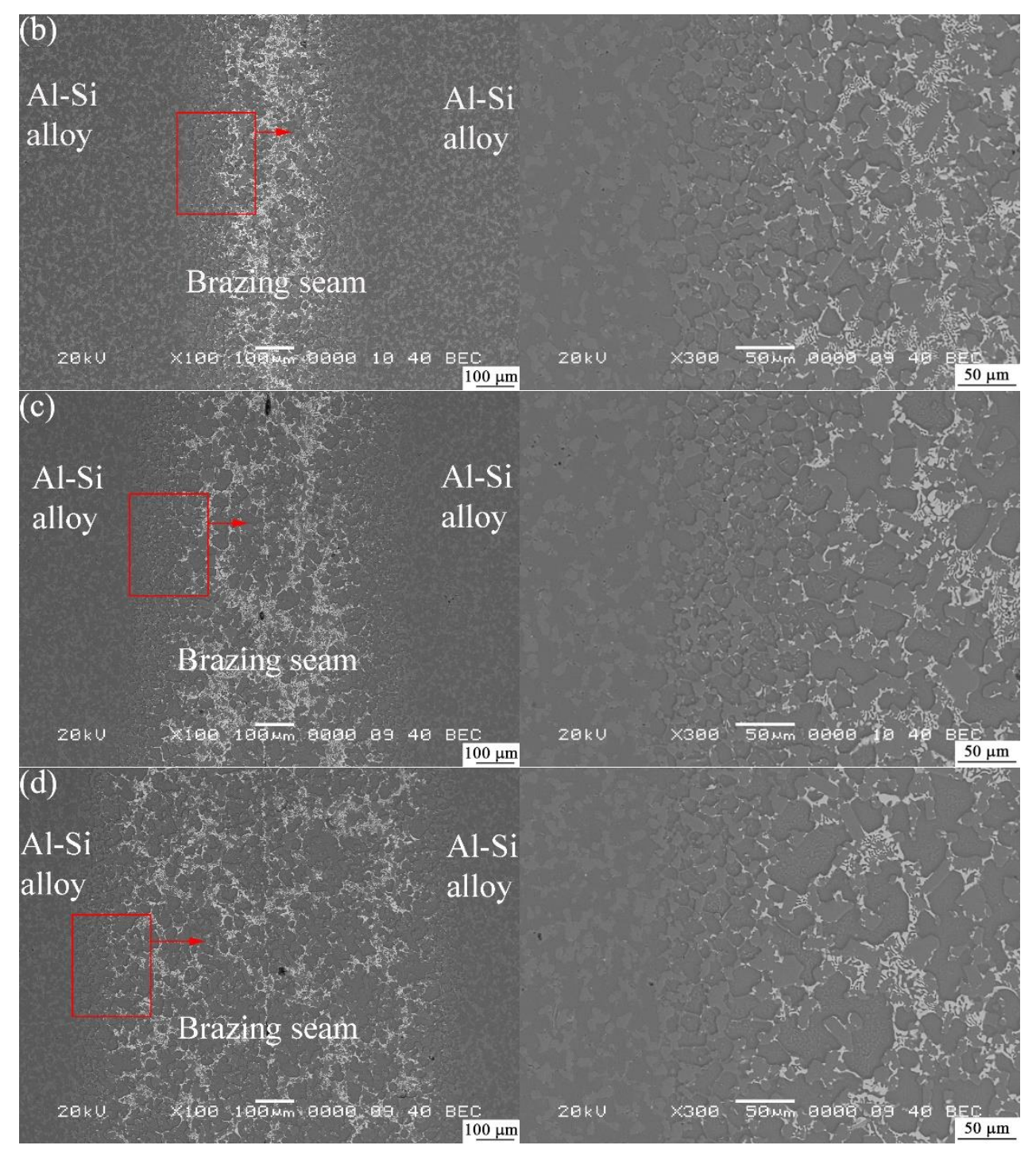

Figure 5. Interfacial evolution on the brazing seam in joints brazed at $540{ }^{\circ} \mathrm{C}$ with different holding times: (a) $7.5 \mathrm{~min}$, (b) $10 \mathrm{~min}$, (c) $12.5 \mathrm{~min}$, and (d) $15 \mathrm{~min}$.

The formation of the Al-Cu compound is the diffusion of $\mathrm{Cu}$ atoms from the center of the brazing seam to the base metal [29]. In order to observe the diffusion of $\mathrm{Cu}$ atoms and distribution of Al-Cu compounds and Si particles, the region from the center of the brazing seam to the base material of the sample with holding a time of 7.5 to $15 \mathrm{~min}$ was subjected to elemental scanning using EDS to observe the diffusion of $\mathrm{Cu}$ element and the change of $\mathrm{Si}$ distribution. It can be clearly seen from the elemental distribution of $\mathrm{Cu}$ atoms in Figure 6 that the distance of diffusion of $\mathrm{Cu}$ into the Al-Si base metal became longer with the holding time prolonging. Cu element in the brazing seam was mainly in the form of the Al-Cu eutectic compound, which is consistent with the phenomenon that the $\mathrm{Al}-\mathrm{Cu}$ compound migrated into the base metal. Another phenomenon in Figure 6 is the obvious change in Si phases. When the holding time was $7.5 \mathrm{~min}$, the size of Si particles in the brazing seam was close to that in the base material. When the holding time was extended to $10 \mathrm{~min}$, Si particles in the brazing seam began to be coarsened, but a certain amount of Si particles retained their fine distribution. With the holding time prolonged to $12.5 \mathrm{~min}$ or $15 \mathrm{~min}$, large amounts of $\mathrm{Si}$ particles in the brazing seam were coarsened, and the size of $\mathrm{Si}$ particles in the base material was significantly finer than that in the brazing seam.

From the right column of Figure 5, it can be found that a large amount of Si particles was aggregated at the interface between the base metal and the brazing seam. This 
phenomenon was verified in the mapping scan of Figure 6. When the temperature reached the Al-Si-Cu ternary eutectic temperature, a liquid phase appeared in the brazing seam. But at this time, there were still many Si particles in the solid state. Some of these Si particles existed in the liquid phase, but more Si particles entered on the surface of the liquid phase, that is, at the junction between the base metal and the brazing seam. With the end of the heating and holding process, the liquid phase solidified, with these Si particles staying at the junction. In fact, similar grain growth near the brazing seam was also observed in [30]. The distribution of Si particles in Figures 5a and 6a show that when the holding time was $7.5 \mathrm{~min}$, Si particles at the junction were still very small, and the dense Si particles were distributed at the junction of the base metal and the brazing seam. From the distribution of Si particles in Figures $5 b$ and $6 b$, it can be seen that when the holding time was extended to $10 \mathrm{~min}$, the number of $\mathrm{Si}$ particles at the junction was much less but the size of Si particles was bigger than that at $7.5 \mathrm{~min}$. At this time, a small amount of fine Si particles still existed at the junction. When the holding time was extended to $12.5 \mathrm{~min}$, it can be seen from the Si distribution in Figure $6 \mathrm{c}$ that the fine Si particles almost disappeared at the junction. Compared with the dense particles in the interface at $7.5 \mathrm{~min}$ and $10 \mathrm{~min}$, the interface at $12.5 \mathrm{~min}$ was much "cleaner", and the remained small particles were distributed at the junction. When the holding time was extended to $15 \mathrm{~min}$, as shown in Figure $6 \mathrm{~d}$, the interface is much "cleaner" than before, and Si particles at the interface between the base metal and the brazing seam were grown, and the size was slightly smaller than the size of the Si particles in the brazing seam.

In summary, the holding time needs to be strictly controlled during TLP bonding of Al-Si alloy. A shorter holding time will cause joint defects, while an excessive holding time will change the distribution of elements in the brazing seam and have a deteriorated influence on the performance of joints. Therefore, the microstructure of the brazing seam was observed at higher magnification with the results shown in Figure 7. The size of $\mathrm{Si}$ particles at different holding times was measured and investigated in detail. In the case of the distribution of $\mathrm{Al}_{2} \mathrm{Cu} \mathrm{IMCs}$, they were mainly distributed around Si particles with a network structure. In the case of the size of $\mathrm{Si}$ particles in the brazing seam, since our alloy was made by the spray-forming method, Si was uniformly distributed in the metal matrix, and the particle size of Si particles in the Al-25Si-4Cu- $1 \mathrm{Mg}$ alloy was about 10-15 $\mu \mathrm{m}$. The size of Si particles in the brazing seam at different holding times was compared. It is found that when the holding time was $7.5 \mathrm{~min}$, the size of Si particles was close to that of the base material, and above $90 \%$ of Si particles was below $15 \mu \mathrm{m}$. With the holding time increasing, the size of Si particles in the brazing seam gradually increased. When the holding time was $10 \mathrm{~min}$ and $12.5 \mathrm{~min}$, Si particles reached $25 \mu \mathrm{m}$ and $35 \mu \mathrm{m}$, respectively. When the holding time reached $15 \mathrm{~min}$, Si particles with a size of $45 \mu \mathrm{m}$ were produced. As the time increased, the coarsened Si not only increased in number but also increased in size, which would deteriorate the mechanical properties of the joint. The shear properties of the joint are also confirmed in a later section. 
Base

center

$\mathrm{Al}$

$\mathrm{Si}$

$\mathrm{Cu}$

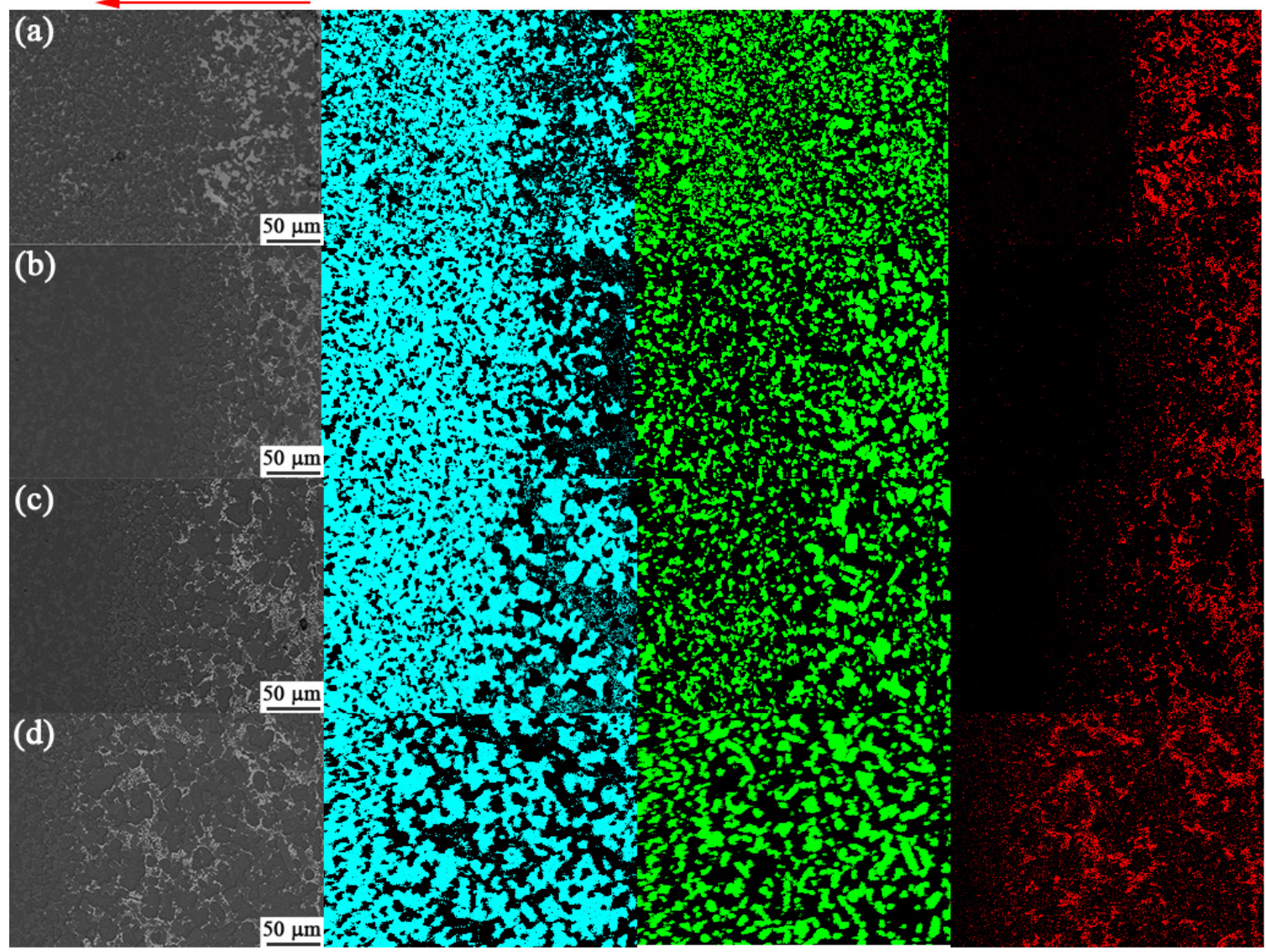

Figure 6. Element distribution from the center of the brazing seam to the base metal at different holding times: (a) $7.5 \mathrm{~min}$, (b) $10 \mathrm{~min},(\mathbf{c}) 12.5 \mathrm{~min}$, and (d) $15 \mathrm{~min}$.
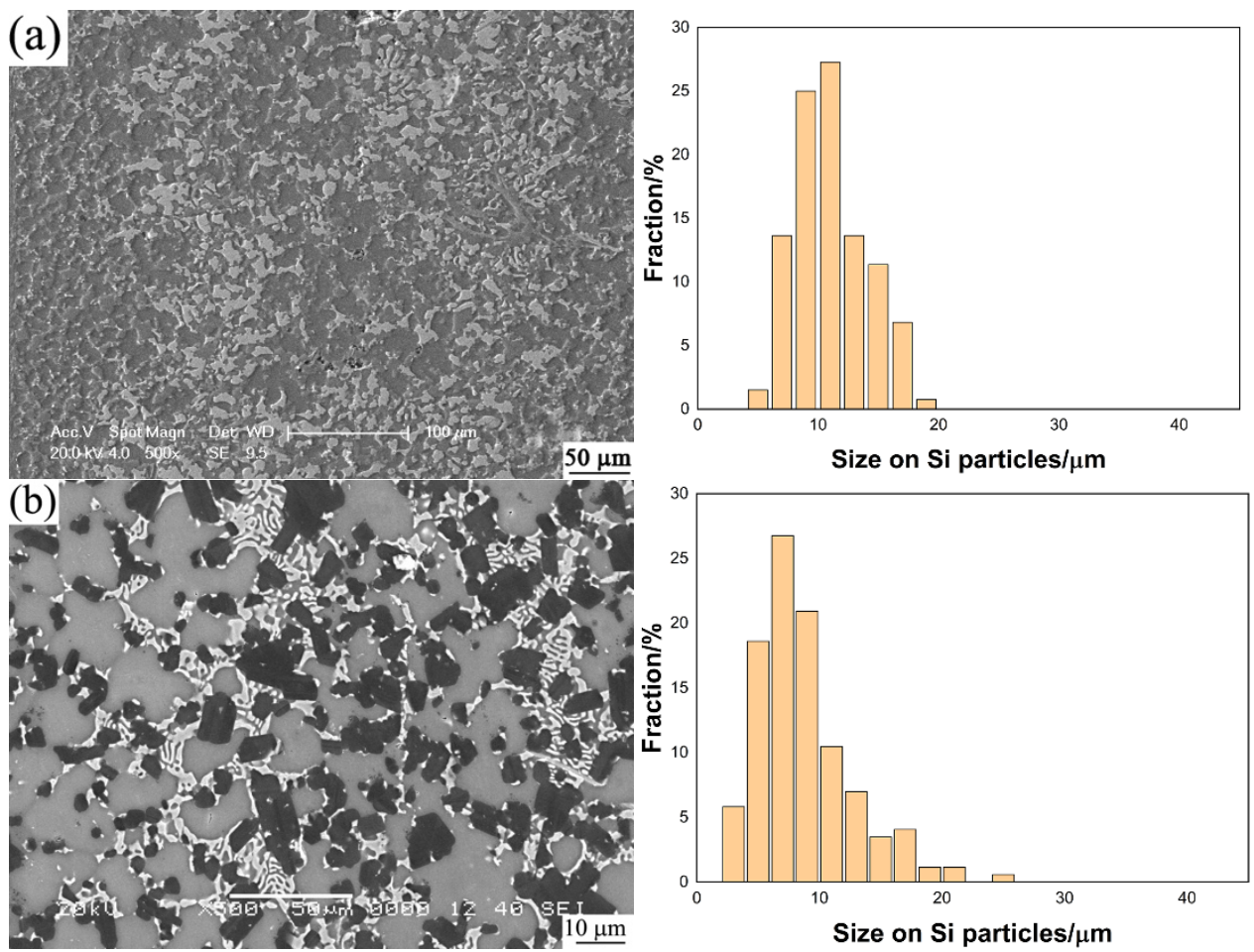

Figure 7. Cont. 

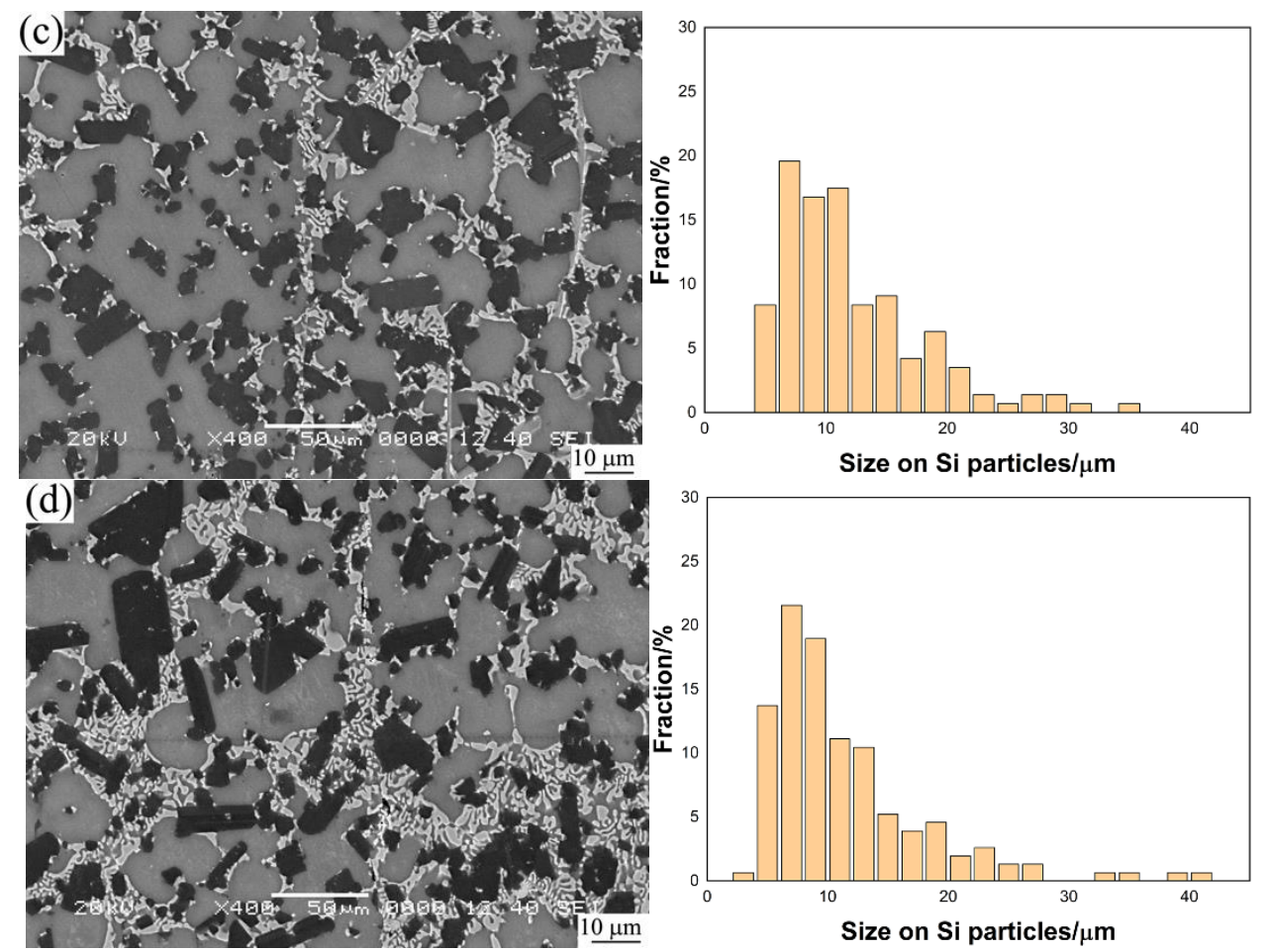

Figure 7. Micro-morphologies and particle size statistics of Si particles under different holding time: (a) $7.5 \mathrm{~min}$, (b) $10 \mathrm{~min},(\mathbf{c}) 12.5 \mathrm{~min}$, and (d) $15 \mathrm{~min}$.

Figure 8 shows the model on the formation of the micro-morphology in the joint. Figure 8a shows the initial state before bonding. The formation of the joint is achieved by element diffusion. $\mathrm{Al}$ in the base metal has strong miscibility with $\mathrm{Cu}$ and will inter diffuse with $\mathrm{Cu}$ in the presence of a concentration gradient. At high temperature, the majority of Si remains in the solid state. The formation of a joint is divided into two parts: the mutual diffusion between $\mathrm{Al}$ and $\mathrm{Cu}$ and the migration of $\mathrm{Si}$ atoms into the brazing seam. In the mutual diffusion between $\mathrm{Al}$ and $\mathrm{Cu}, \mathrm{Cu}$ diffuses into the base material. Since the grain size of $\mathrm{Al}$ atoms is larger than that of $\mathrm{Cu}$ atoms, it is easier for $\mathrm{Cu}$ atoms to enter the grain lattice of $\mathrm{Al}$ during the diffusion process [31]. With the temperature increasing, under the influence of pressure on the sample, the oxide film on the surface of the $\mathrm{Al}$ substrate will have gaps, which are mainly generated at the edge of solid Si particles. When the gap becomes larger, the $\mathrm{Al}$ element in the base metal comes into contact with $\mathrm{Cu}$. Because there is only $4 \% \mathrm{Cu}$ in the base material, the concentration difference between the brazing seam and the base material will be produced at this time, and accordingly, $\mathrm{Cu}$ begins to diffuse into the base material. When the temperature reaches the eutectic temperature of $\mathrm{Al}-\mathrm{Si}-\mathrm{Cu}$, a small amount of liquid phase begins to form at the joint, as shown in Figure 8b; the initially generated liquid phase will also affect the oxide film. With the temperature increasing, more liquid phases are generated, the oxide film becomes smaller and the contact area between the base material and the intermediate layer $\mathrm{Cu}$ becomes larger, Finally, all $\mathrm{Cu}$ reacts with $\mathrm{Al}$ near the brazing seam to produce a eutectic solution, as shown in Figure 8c. With the diffusion continuing, $\mathrm{Cu}$ atoms enter into the base material in the form of Al-Cu intermetallic compounds. These eutectic fluids flow along the grain boundaries of $\alpha-\mathrm{Al}$ and Si phases, while $\mathrm{Cu}$ in the $\mathrm{Al}-\mathrm{Cu}$ compound will continue to enter $\alpha-\mathrm{Al}$, resulting in the decrease in $\mathrm{Cu}$ element concentration. Accordingly, $\mathrm{Cu}$ element concentration is equivalent to the base material, and the diffusion tends to stop. At this time, most Si still exists in a solid form. These Si elements will not flow to the base material with the eutectic solution, and the smaller Si particles will gradually evolve into larger Si particles. After the heating and holding process is complete, the eutectic liquid phase into the base metal will begin to solidify, and the dendritic Al-Cu eutectic phase 
is gradually formed. The original small Si particles in the base metal also become to be coarsened, as shown in Figure 8d. It is possibly induced by the ternary eutectic reaction of $\mathrm{Al}, \mathrm{Si}$, and $\mathrm{Cu}$ after the temperature reaching the eutectic temperature. However, when the temperature sets at $540{ }^{\circ} \mathrm{C}$, the actual composition of the resulting liquid phase will deviate from the ternary eutectic composition, where the content of Si will be less than the ternary eutectic composition. At this time, most $\mathrm{Si}$ will not be dissolved. As can be seen from point $A$ in the ternary phase diagram shown in Figure 9, the solidified phase at this time is an $\mathrm{Al}-\mathrm{Cu}$ binary eutectic phase $\left(\theta-\mathrm{Al}_{2} \mathrm{Cu}+\mathrm{Al}\right)$. The actual composition of the residual liquid phase will reach the ternary eutectic composition, as shown at point $B$ in Figure 9. Therefore, the solidification path is probably with the following sequence:

$$
\mathrm{L} \rightarrow \mathrm{L}_{\text {residual }}+\theta \cdot \mathrm{Al}_{2} \mathrm{Cu}+\mathrm{Al} \rightarrow \theta \cdot \mathrm{Al}_{2} \mathrm{Cu}+\mathrm{Al}+\mathrm{Si}
$$

among which the main eutectic should be Al-Cu eutectic phase. With the increase in holding time, the fine Si particles will be aggregated and coarsened under the flow of the eutectic liquid phase. This produces great advantages compared to the traditional solidification process after the fusion welding of high eutectic Al-Si and the process of casting high eutectic Al-Si alloy. Due to the high temperature of fusion welding and casting, Si content in the liquid phase will exceed the ternary eutectic composition, and the Si phase will be first precipitated during solidification, which will greatly deteriorate the mechanical properties of the joint.
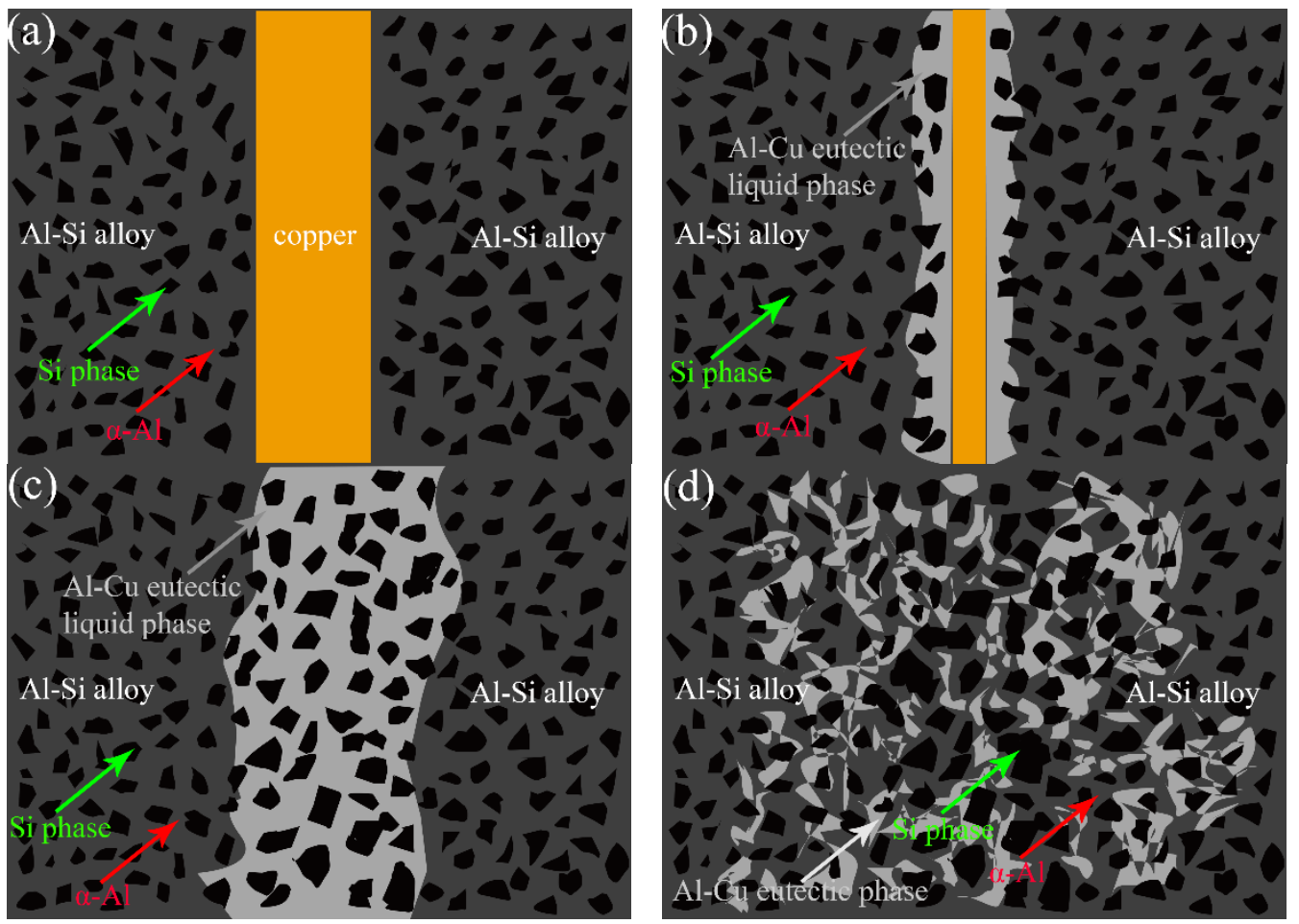

Figure 8. Schematic diagram of the formation process of $\mathrm{Al}-25 \mathrm{Si}-4 \mathrm{Cu}-1 \mathrm{Mg} / \mathrm{Cu}$ braze under vac-uum environment and brazing temperature $540{ }^{\circ} \mathrm{C}$ : (a) initial state; (b) formation of Al-Cu eutec-tic phase; (c) complete consumption of $\mathrm{Cu}$ interlayer and (d) formation of TLP joint. 


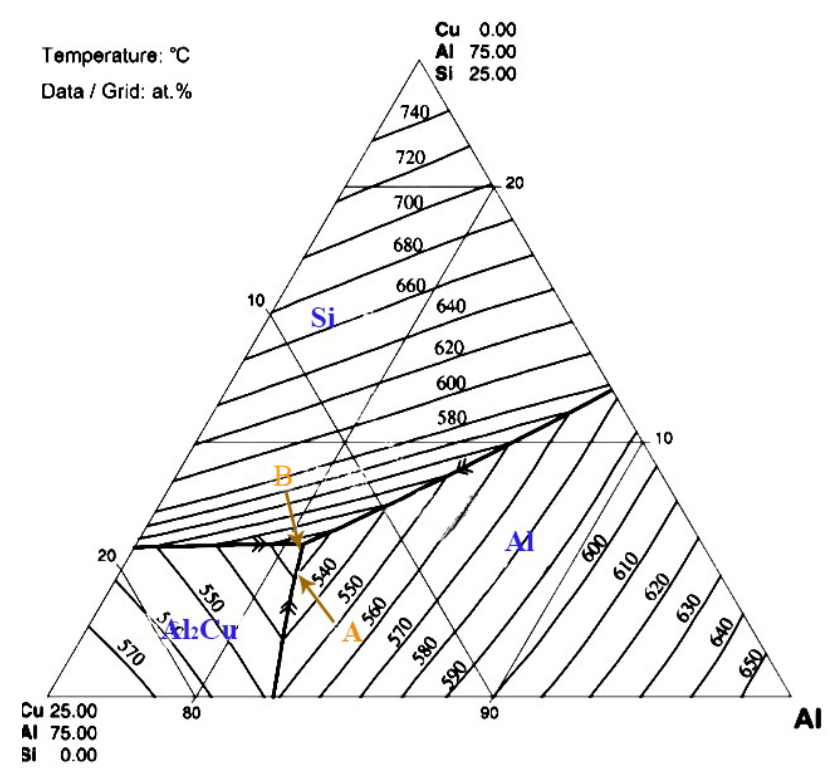

Figure 9. Al-Cu-Si ternary phase diagram at the Al-rich corner [32].

\subsection{Mechanical Properties of TLP Joints}

The shear properties of brazing joints were tested, and the shear strength of joints was calculated according to the maximum load. The results at different brazing temperatures and holding times are plotted in Figure 10. During the effect of brazing temperature, as can be seen from Figure 10a, the shear strength of the joint reached the maximum at $540{ }^{\circ} \mathrm{C}$. At $535{ }^{\circ} \mathrm{C}$ and a retention time of $10 \mathrm{~min}$, the shear strength was approximately $30 \mathrm{MPa}$. As the temperature increased to $540{ }^{\circ} \mathrm{C}$, the shear performance reached a maximum value of about $50 \mathrm{MPa}$. With the temperature continuously increasing, the shear strength of the joint decreased slightly. The reason may be attributed to the formation of more $\mathrm{Al}_{2} \mathrm{Cu}$ IMCs in the joint. Voids also began to appear in the joint. Excessive IMCs and voids will reduce the mechanical properties of the joint. During the effect of holding time, as can be seen from Figure 10b, when the holding time was $5 \mathrm{~min}$, a large number of voids were produced in the joint, which induced poor mechanical properties. With the holding time reaching $7.5 \mathrm{~min}$, the shear strength of joints reached the maximum, about $75 \mathrm{MPa}$. With the holding time furtherly increasing, the shear property of the joint gradually decreased. With $15 \mathrm{~min}$ holding time, the shear strength of the joint was only $22 \mathrm{MPa}$, which was even lower than that of joints with a holding time of 5 min. From Figure 10b, it can be seen that the joint with longer holding times but without defects would be even weaker than that with defects produced at a shorter holding time. When the holding time was $7.5 \mathrm{~min}$, the brazing seam was mainly composed of distributed Al-Cu IMCs, $\alpha$-Al phase, and finer Si particles with sizes within $20 \mu \mathrm{m}$. They had pinning effects on the microstructure, and furthermore, $\mathrm{Si}$ particles in the brazing seam were tightly combined with the adjacent aluminum-based solid solution, which provided the expansion resistance for cracks generated by the external force and then enhanced the mechanical properties of joints. With a prolonged holding time, $\mathrm{Al}-\mathrm{Cu}$ intermetallic compounds gradually changed from a sheet-like uniform distribution to a dendritic aggregation distribution, and Si phases were obviously coarsened in the brazing seam. Moreover, large amounts of Si particles were segregated at the interface between the brazing seam and base metal and would seriously deteriorate the mechanical properties of joints, which was confirmed by observation on the later fracture analysis. 

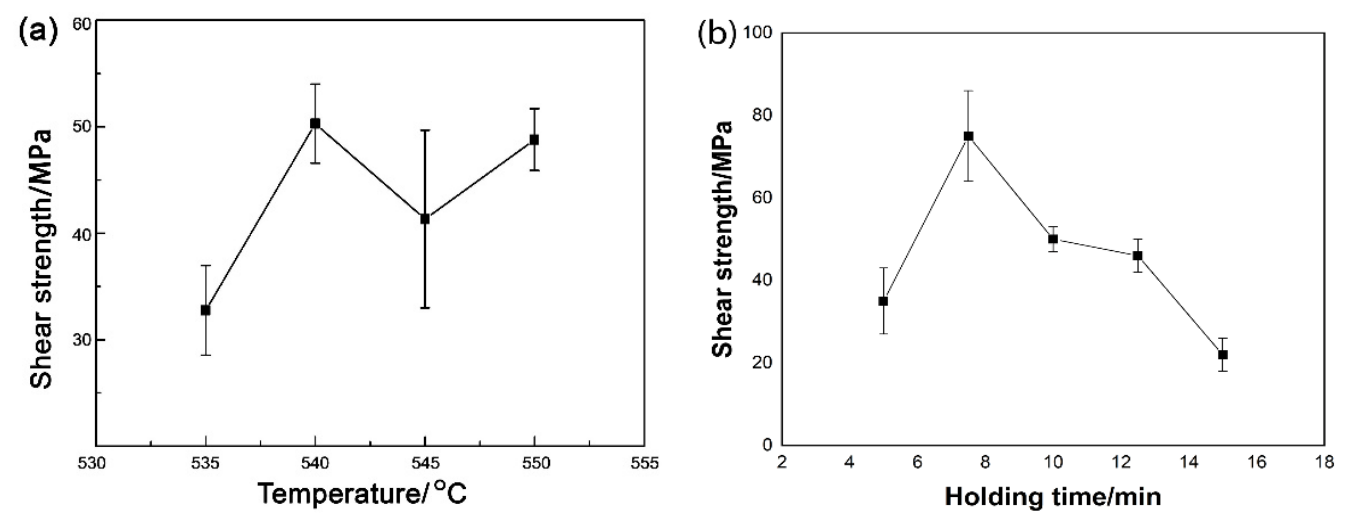

Figure 10. Effect of brazing temperature (a) and holding time (b) on the shear strength of joints.

Figure 11 shows the typical fracture morphologies of joints finished at the brazing temperature of $540^{\circ} \mathrm{C}$. Figure $11 \mathrm{a}$ is the side profile of the fracture, and the fracture occurred within the base metal. Figure $11 \mathrm{~b}$ is the observation of the fracture from the top view. The left part is the brazing seam and the right part is the base metal. Combined with Figure 11a, the fracture position should occur along the interface between two pieces of base metals. Figure 11c shows the magnified observation of the red area in Figure 11b, it can be seen that the fracture surface is smooth without the appearance of dimples, which belongs to a typical brittle fracture. There are some small white spots in the fracture, which are the primary Si. From the observation of the interfacial structure shown in Figures 3 and 4, the continuous reticulate $\mathrm{Al}_{2} \mathrm{Cu}$ IMCs and coarsened Si particles at the interface of brazing joints had a deteriorating effect on the shear properties of the joints, which induced the fracture propagating along the center within the brazing seam, as shown in Figure 11d.
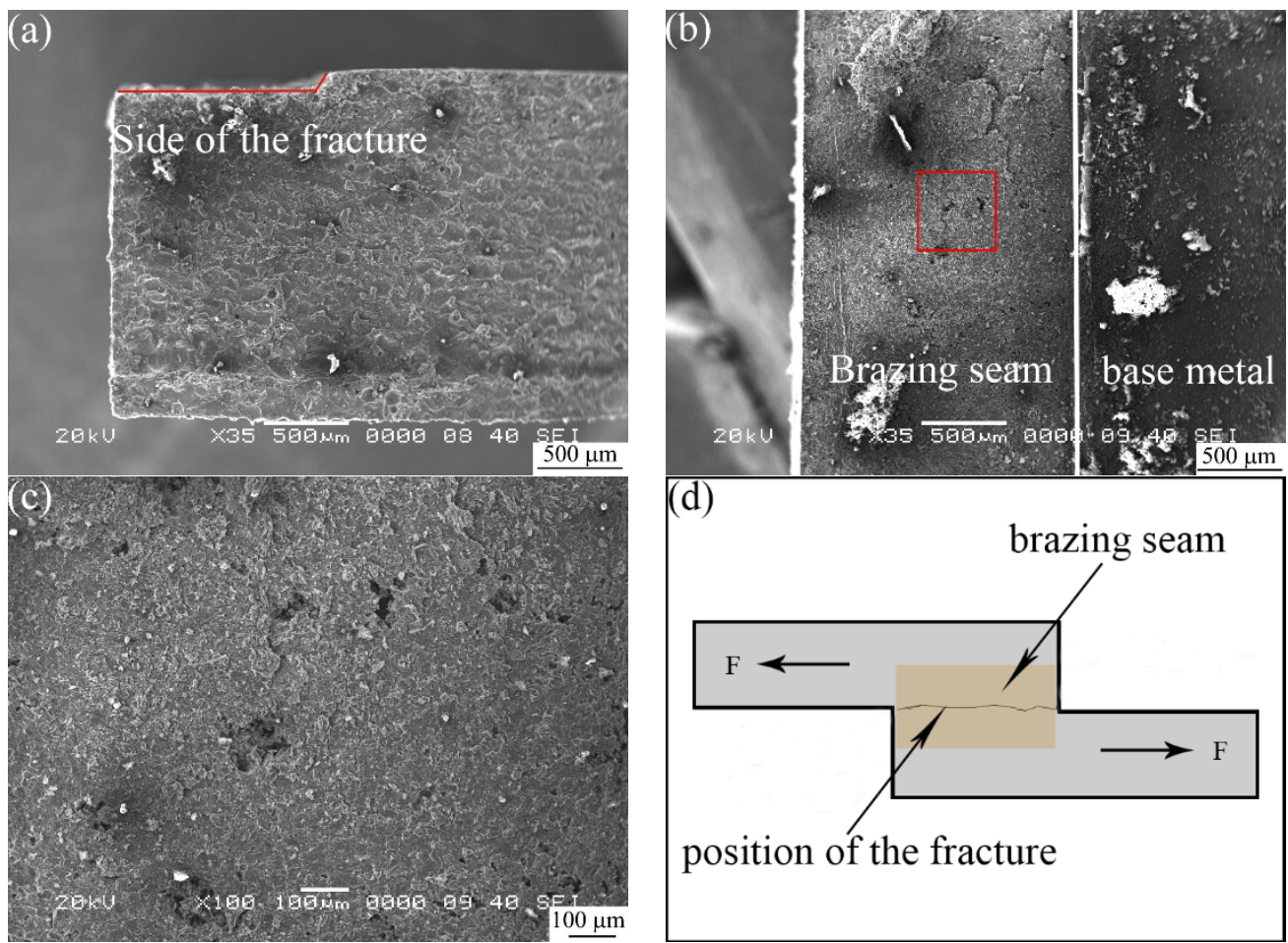

Figure 11. Fracture morphology of the joint brazed at $540{ }^{\circ} \mathrm{C}$ for $10 \mathrm{~min}$ : (a) side view, (b) top view, (c) magnified read area, and (d) path on the fracture propagation.

Figure 12 shows SEM images on the fracture morphology and the fracture propagation that occurred in the joint bonded at $540{ }^{\circ} \mathrm{C}$ for $7.5 \mathrm{~min}$. From the side and top observations, 
as shown in Figure 12a,b, the fracture mainly occurred at the interface between the brazing seam and base metal, as shown in Figure 12d, which was different from the joint with a longer holding time in Figure 11d. It can also be seen that the fracture mode is a quasi-plastic fracture with observable Si particles. The fracture mainly occurred in the base metal, while a longer holding time would cause the fracture to occur at the interface in the brazing seam.

The mechanical properties with a holding time of $7.5 \mathrm{~min}$ are better than the mechanical properties with a holding time of $10 \mathrm{~min}$. The reason is related to the fracture position of the joint. When the holding time was $7.5 \mathrm{~min}$, the joint fractured at the junction of the brazing seam and the base metal. According to the element distribution in Figure 6a, the fracture location was at the Si particle aggregation area between the base material and the brazing seam. From Figure 7a, the size of Si particles was smaller and the IMC distribution was uniform at the brazing seam with a holding time of $7.5 \mathrm{~min}$. In combination with the fracture side view of Figure 11a, the weakness of the joints was located in the area between the brazing seam and the base metal with Si particle aggregation. A large amount of Si particles aggregate was detrimental to the strength of the joint because they were easily cracked under lower stress. However, when the holding time was extended to $10 \mathrm{~min}$, the joint was broken at the center of the brazing seam. In view of Figure $6 \mathrm{~b}$, a large number of coarse Si particles can be seen at the brazing seam. This coarse primary crystal phase will deteriorate the strength of the joint. With the extension of the holding time, the shear strength of the joint will gradually decrease, which was consistent with the result of Figure 10b. It can be seen from Figures 6 and 7 that when the holding time reached $12.5 \mathrm{~min}$ and $15 \mathrm{~min}$, long Si particles appeared in the brazing seam. The mechanical properties of this Si were more unfavorable for the joints [20].
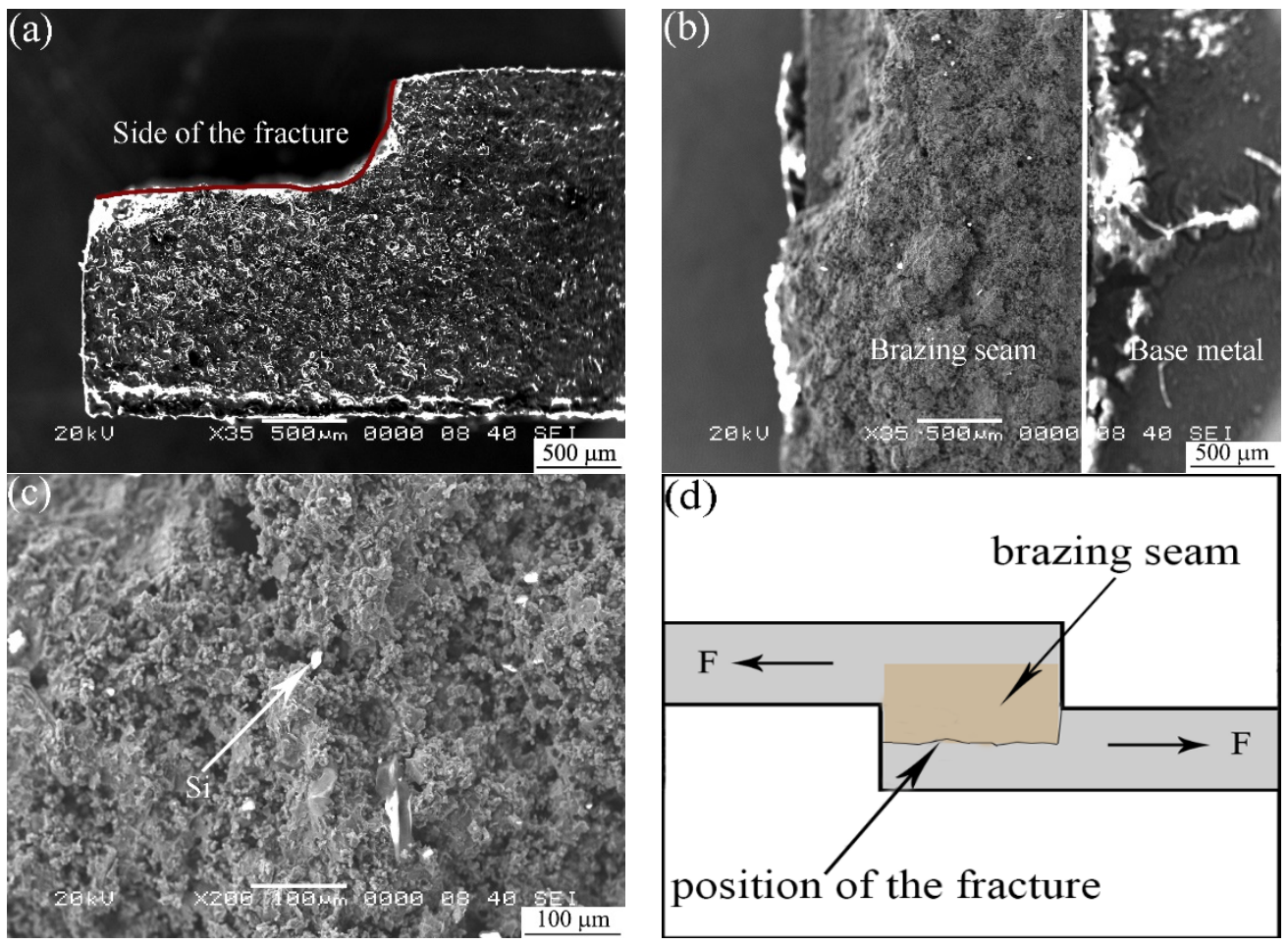

Figure 12. Fracture morphology of the joint brazed at $540{ }^{\circ} \mathrm{C}$ for $7.5 \mathrm{~min}$ : (a) side view, (b) top view, (c) magnified read area, and (d) path on the fracture propagation.

\section{Conclusions}

In this paper, $\mathrm{Al}-25 \mathrm{Si}-4 \mathrm{Cu}-1 \mathrm{Mg}$ spray-formed alloy was brazed by the TLP method with $30 \mu \mathrm{m} \mathrm{Cu}$ foil as the intermediate brazing metal. Different joints were obtained by changing the brazing process parameters. The microstructure and properties of joints were investigated. The following results can be concluded: 
(1) Al-25Si-4Cu-1Mg spray-formed hypereutectic alloy can be successfully bonded by the transient liquid phase bonding method with $\mathrm{Cu}$ as an interlayer. The appropriate process parameter was obtained. When the brazing temperature was $540{ }^{\circ} \mathrm{C}$, and the holding time was $7.5 \mathrm{~min}$, the joint interface reached the best without obvious defects such as cracks and voids, and with the highest shear strength of about $75 \mathrm{MPa}$.

(2) The brazing seam was mainly composed of $\mathrm{Al}_{2} \mathrm{Cu}$-based intermetallic compounds, $\alpha$-Al phase, and primary Si. The increase in the bonding temperature produced more voids in the brazing seam.

(3) With a prolonged holding time, the diffusion of $\mathrm{Cu}$ into the base metal obviously occurred during TLP bonding, which induced a wider brazing seam. With a shorter holding time, the microstructure presented fine Sn distribution in the seam, but with the extension of holding time, the size of Si particles was easily coarsened, which greatly deteriorated the mechanical properties of the joint.

Author Contributions: Conceptualization, F.W.; methodology, F.W. and G.X.; analysis, K.Q.; writingoriginal draft preparation, G.X.; writing-review and editing, F.W. All authors have read and agreed to the published version of the manuscript.

Funding: This research was funded by the National Natural Science Foundation of China, grant No. 51875269.

Institutional Review Board Statement: Not applicable.

Informed Consent Statement: Not applicable.

Data Availability Statement: Not applicable.

Acknowledgments: This work was also sponsored by Qing Lan Project from Jiangsu Province.

Conflicts of Interest: The authors declare no conflict of interest.

\section{References}

1. Cai, Z.; Zhang, C.; Wang, R.; Peng, C.; Qiu, K.; Feng, Y. Preparation of Al-Si alloys by a rapid solidification and powder metallurgy route. Mater. Des. 2015, 87, 996-1002. [CrossRef]

2. Cui, C.; Schulz, A.; Epp, J.; Zoch, H.W. Deformation behavior of spray-formed hypereutectic Al-Si alloys. J. Mater. Sci. 2010, 45, 2798-2807. [CrossRef]

3. Cui, C.; Schulz, A.; Schimanski, K.; Zoch, H.W. Spray forming of hypereutectic Al-Si alloys. J. Mater. Process. Technol. 2009, 209, 5220-5228. [CrossRef]

4. Yu, W.; Zhang, Y.; Yan, T.; Liu, Y.; Jiang, A.; Zheng, H.; Tian, X. Enhanced nucleation of primary silicon in Al-20 wt. \% Si alloy with Ni-Si inoculation. J. Alloy. Compd. 2017, 693, 303-307. [CrossRef]

5. Timpel, M.; Wanderka, N.; Schlesiger, R.; Yamamoto, T.; Lazarev, N.; Isheim, D.; Schmitz, G.; Matsumura, S.; Banhart, J. The role of strontium in modifying aluminium-silicon alloys. Acta Mater. 2012, 60, 3920-3928. [CrossRef]

6. Ma, P.; Jia, Y.; Prashanth, K.G.; Yu, Z.; Li, C.; Zhao, J.; Yang, S.; Huang, L. Effect of Si content on the microstructure and properties of Al-Si alloys fabricated using hot extrusion. J. Mater. Res. 2017, 32, 2210-2217. [CrossRef]

7. Prasad, S.V.; Asthana, R. Aluminum Metal-Matrix Composites for Automotive Applications: Tribological Considerations. Tribol. Lett. 2004, 17, 445-453. [CrossRef]

8. Anil, M.; Srivastava, V.C.; Ghosh, M.K.; Ojha, S.N. Influence of tin content on tribological characteristics of spray formed Al-Si alloys. Wear 2010, 268, 1250-1256. [CrossRef]

9. Liu, M.; Cui, Z.; Li, Y. Modeling and Simulation of Porosity in Spray Deposition. Metall. Mater. Trans. B 2019, 50, 1908-1920. [CrossRef]

10. PGrant, S.; Kim, W.T.; Cantor, B. Spray forming of aluminium-copper alloys. Mater. Sci. Eng. A 1991, 134, 1111-1114. [CrossRef]

11. Ojha, K.V.; Tomar, A.; Singh, D.; Kaushal, G.C. Shape, microstructure and wear of spray formed hypoeutectic Al-Si alloys. Mater. Sci. Eng. A 2008, 487, 591-596. [CrossRef]

12. Zhu, X.-W.; Wang, R.-C.; Peng, J.; Peng, C.-Q. Microstructure evolution of spray-formed hypereutectic Al-Si alloys in semisolid reheating process. Trans. Nonferrous Met. Soc. China 2014, 24, 1766-1772. [CrossRef]

13. Zhu, X.; Wang, R.; Peng, C.; Liu, W.; Peng, J. Microstructure and thermal expansion behavior of spray-formed Al-27Si alloy used for electronic packaging. J. Mater. Sci. Mater. Electron. 2014, 25, 4889-4895. [CrossRef]

14. Zhang, W.; Qiu, X.; Sun, D.; Zhao, X. Microstructure and mechanical properties of $\mathrm{CO}_{2}$ laser welded joint of ZL109 aluminum silicon alloy. Trans. China Weld. Inst. 2010, 31, 45-48.

15. Lotfi, B.; Rostami, M.; Sadeghian, Z. Effect of silicon content on microstructure of Al-Si/SiCp composite layer cladded on A380 Al alloy by TIG welding process. Trans. Nonferrous Met. Soc. China 2014, 24, 2824-2830. [CrossRef] 
16. Liu, H.; Hu, Y.; Zhao, Y. Microstructural characteristics and formation mechanism of friction stir welds of SiC particulates reinforced Al-Si matrix composites. Mater. Lett. 2015, 158, 136-139. [CrossRef]

17. Roy, P.; Pal, T.K.; Maity, J. Transient Liquid Phase Diffusion Bonding of 6061Al-15 wt.\% SiC p Composite Using Mixed Cu-Ag Powder Interlayer. J. Mater. Eng. Perform. 2016, 25, 3518-3530. [CrossRef]

18. Zhang, G.; Cai, J.; Chen, B.; Xu, T. Availability of in-situ reinforced active-transient liquid phase bond with good wettability for 70 vol.\% SiCp/A356 composite using Al-Mg-Ga-Ti interlayer. Mater. Des. 2016, 110, 653-662. [CrossRef]

19. Wang, Q.; Chen, X.; Zhu, L.; Yan, J.; Lai, Z.; Zhao, P.; Bao, J.; Lv, G.; You, C.; Zhou, X.; et al. Rapid ultrasound-induced transient-liquid-phase bonding of Al-50Si alloys with Zn interlayer in air for electrical packaging application. Ultrason. Sonochem 2017, 34, 947-952. [CrossRef]

20. Wang, Q.; Zhu, L.; Chen, X.; Yan, J.; Xie, R.; Li, P.; Wang, Z.; Wang, Z.; Li, Y.; Zhou, X. Si particulate-reinforced ZnAl based composites joints of hypereutectic Al50Si alloys by ultrasonic-assisted soldering. Mater. Des. 2016, 107, 41-46. [CrossRef]

21. Zhu, L.; Wang, Q.; Shi, L.; Zhang, X.; Yang, T.; Yan, J.; Zhou, X.; Chen, S. Ultrarapid formation of multi-phase reinforced joints of hypereutectic Al-Si alloys via an ultrasound-induced liquid phase method using Sn-51In interlayer. Mater. Sci. Eng. A 2018, 711, 94-98. [CrossRef]

22. Xu, L.; Wang, H.; Sun, Q.; Wan, W.; Chen, H. Effect of bonding temperature on microstructure and shear strength of the dissimilar $\mathrm{Al} / \mathrm{Al}-27 \mathrm{Si}$ joints bonded by partial transient liquid phase bonding. J. Manuf. Process. 2019, 41, 297-306. [CrossRef]

23. Sun, Q.; Wang, H.; Yang, C. Microstructure and Properties of the Al-27Si/Cu/Al-50Si Joint Brazed by the Partial Transient Liquid Phase Bonding. Metall. Mater. Trans. B 2018, 49, 1-6. [CrossRef]

24. Lee, S.-W.; Kim, M.-S. High temperature deformation behavior of spray-formed and subsequently extruded Al-25Si based alloy. Met. Mater. Int. 2016, 22, 579-584. [CrossRef]

25. Feng, D.; Zhu, T.; Zang, Q.; Lee, Y.; Fan, X.; Zhang, H. Solution behavior of spray formed hypereutectic AlSiCuMg alloy. Acta Metall. Sin. 2021. [CrossRef]

26. Huang, H.J.; Cai, Y.H.; Cui, H.; Huang, J.F.; He, J.P.; Zhang, J.S. Influence of Mn addition on microstructure and phase formation of spray-deposited Al-25Si-xFe-yMn alloy. Mater. Sci. Eng. A 2009, 502, 118-125. [CrossRef]

27. Goudar, D.M.; Raju, K.; Srivastava, V.C.; Rudrakshi, G.B. Effect of secondary processing on the microstructure and wear behavior of spray formed Al-30Mg2Si-2Cu alloy. Mater. Des. 2013, 47, 489-496. [CrossRef]

28. Cai, Z.; Zhang, C.; Wang, R.; Peng, C.; Wu, X. Effect of copper content on microstructure and mechanical properties of Al/Sip composites consolidated by liquid phase hot pressing. Mater. Des. 2016, 110, 10-17. [CrossRef]

29. Zhang, W.; Ao, S.; Oliveira, J.P.; Li, C.; Zeng, Z.; Wang, A.; Luo, Z. On the metallurgical joining mechanism during ultrasonic spot welding of NiTi using a Cu interlayer. Scr. Mater. 2020, 178, 414-417. [CrossRef]

30. Oliveira, J.P.; Shen, J.; Escobar, J.D.; Salvador, C.A.F.; Schell, N.; Zhou, N.; Benafan, O. Laser welding of H-phase strengthened Ni-rich NiTi-20Zr high temperature shape memory alloy. Mater. Des. 2021, 202, 109533. [CrossRef]

31. Eizadjou, M.; Kazemitalachi, A.; Daneshmanesh, H.; Shakurshahabi, H.; Janghorban, K. Investigation of structure and mechanical properties of multi-layered $\mathrm{Al} / \mathrm{Cu}$ composite produced by accumulative roll bonding (ARB) process. Compos. Sci. Technol. 2008, 68, 2003-2009. [CrossRef]

32. Effenberg, G.; Ilyenko, S. Crystallographic and Thermodynamic Data, Light Metal Systems, Part 1: Selected Systems form Al-Cu-Fe to Al-Fe-Ti; Springer: Berlin Heidelberg, Germany, 2005; pp. 135-147. 